\title{
Enhancing Environmental Literacy in K-12 Science Classrooms
}

\author{
Hayat Hokayem ${ }^{1 *}$, Hui Jin $2^{\star \star}$ \\ ${ }^{1}$ Andrews Institute of Mathematics \& Science Education, Texas Christian University, College of Education, Fort Worth, TX, USA \\ ${ }^{2}$ Center of Student and Teacher Research, Research \& Development, Educational Testing Service, Princeton, NJ, USA
}

Despite technological advances and policy efforts, environmental problems such as climate change, biodiversity loss, competition for energy resources, access to clean water, air pollution, and land degradation, remain fundamental challenges for human societies in the $21^{\text {st }}$ century. To tackle these environmental challenges, an important goal of K-12 science education is to enhance environmental literacy - the ability of students to master scientific knowledge and practices that will prepare them to analyze, interpret, and evaluate critical issues in complex natural and human systems, in order to make responsible and informed decisions about the environment. To contribute to the efforts to promote environmental literacy, the Eurasia Journal of Mathematics, Science and Technology Education, presents this special issue: Enhancing Environmental Literacy in K-12 Science Classrooms. This special issue contains nine articles focusing on teaching and learning of environmental issues.

Five articles focus on teachers' environmental literacy and their abilities to promote students' environmental literacy. Two of these articles explore factors that may affect teachers' knowledge and teaching of environmental issues. Kidman and Casinader notice that, although the teachers' environmental literacy is the prerequisite for promoting environmental literacy in students, research of teachers' environmental literacy is sparse. They examined the Australian science curriculum and found that it did not cover major sustainability ideas and critical inquiry-based practices, and therefore fell short in providing guidance for teachers. Lee, Chu, and Martin developed an instrument measuring teachers' environmental pedagogical content knowledge (ePCK). They examined factors influencing elementary teachers' ePCK and found that teachers who completed a graduate degree designed to improve ePCK in environmental education tend to have a higher-level of ePCK. The authors of the other three articles in this category investigated how professional development opportunities and teaching methods courses promote teachers' knowledge and teaching of environmental issues. Breslyn and Mcginnis conducted a study on how computational thinking, with an emphasis on complex systems, influences elementary preservice teachers' knowledge and teaching of climate change. They found that, after appropriate instruction, the preservice teachers were able to explain the relationships among various variables related to climate change, and they were also able to incorporate systems thinking in proposed teaching of sea level rising, a key topic in climate change. Owens, Herman, Orteli, Lanni, and Sadler explored the role of the socio-scientific reasoning in understanding complex environmental issues. They investigated how a professional development course with science and mathematics teachers positively influenced teachers' socio-scientific reasoning and provided teachers with tools to evaluate their students' understanding of complex environmental issues. Bloom and Quebec-Fuentes examined the effect of authentic experiential learning on in-service teachers' knowledge of energy sources and sustainability. They report on positive gains in teachers' content knowledge and propose ways to transfer those learning gains to classroom teaching.

Four articles focus on students' environmental literacy. Mittenzwei, Buckermann, Nordine, and Harms provide a systematic literature review on the dynamic relationships between the knowledge of energy and the knowledge of climate change. The review suggests a need for more research to investigate an energy-related learning progression on the topic of climate change. Zhao, Anderson, Scott, Draney, and Kim conducted a cross-cultural study that uses a learning progression approach to compare how U.S. students and Chinese students reason about matter and energy in the carbon cycle. They found that reasoning across scales is a significant challenge for both U.S. students and Chinese students. Moreover, due to the cultural and curricular differences in the two countries, U.S. students and Chinese students tended to hold different ideas about the structure and growth of organisms and Chinese students were less inclined to write about their informal ideas in the assessment. Irish, Berkowitz, \& Harris investigated secondary students' data exploration skills in an ecology project. Based on the study, they constructed a framework that outlines the data exploration processes in the inquiry practice and in the construction of environmental arguments. Smith, Besalti, Nation, Feldman, and Laux report on a game-based intervention that engaged high school students in analyzing scientific data of local places. The results suggested positive learning gains in understanding climate change.

(C) 2019 by the authors; licensee Modestum Ltd., UK. This article is an open access article distributed under the terms and conditions of the Creative Commons Attribution License (http://creativecommons.org/licenses/by/4.0/). \.hokayem@tcu.edu (*Correspondence) $\square$ hjin@ets.org (**Correspondence) 
Articles in this special issue provide insights in important topics related to environmental literacy, including assessing students' competency in using scientific core ideas and practices to understand and analyze environmental issues, teacher preparation and professional development in environmental science education, and the use of advanced technology in environmental education. Nonetheless, further empirical work is needed. In particular, more research is needed to identify the affordances and challenges of implementing inter-disciplinary curricula that promote environmental literacy. Although technology has been used in science education, more work is required to identify how specific practices in tandem with technology use support environmental literacy. More cross-cultural studies are needed to flesh out how the cultural and curricular similarities and differences affect student learning of environmental issues. We hope this special issue will facilitate the conversation about environmental literacy and inspire researchers to conduct further research to promote teaching and learning of environmental issues in K-12 science classrooms.

\section{REFERENCES}

( ${ }^{*}$ These are articles published in this special issue.)

*Bloom, M., Quebec Fuentes, S. (2019). Experiential Learning for Enhancing Environmental Literacy Regarding Energy: A Professional Development Program for Inservice Science Teachers. Eurasia Journal of Mathematics, Science and Technology Education, 15(6), em1699. https:/ / doi.org/10.29333/ ejmste/103571

*Breslyn, W., McGinnis, J. R. (2019). Investigating Preservice Elementary Science Teachers' Understanding of Climate Change from a Computational Thinking Systems Perspective. Eurasia Journal of Mathematics, Science and Technology Education, 15(6), em1696. https:// doi.org/10.29333/ ejmste/103566

*Irish, T., Berkowitz, A., Harris, C. (2019). Data Explorations: Secondary Students' Knowledge, Skills and Attitudes Toward Working with Data. Eurasia Journal of Mathematics, Science and Technology Education, 15(6), em1686. https:// doi.org/10.29333/ejmste/103063

*Kidman, G., Casinader, N. (2019). Developing Teachers' Environmental Literacy through Inquiry-based Practices. Eurasia Journal of Mathematics, Science and Technology Education, 15(6), em1687. https://doi.org/10.29333/ejmste/103065

*Lee, Y. J., Chu, H., Martin, S. N. (2018). Examining Factors that Influence on Elementary Teachers' Perceptions in a Graduate Level Interdisciplinary Environmental Education Program: Using ePCK as a Framework. Eurasia Journal of Mathematics, Science and Technology Education, 14(10), em1574. https://doi.org/10.29333/ejmste/92184

*Mittenzwei, D., Bruckermann, T., Nordine, J., Harms, U. (2019). The Energy Concept and its Relation to Climate Literacy. Eurasia Journal of Mathematics, Science and Technology Education, 15(6), em1703. https:// doi.org/10.29333/ ejmste/105637

*Owens, D. C., Herman, B. C., Oertli, R. T., Lannin, A. A., Sadler, T. D. (2019). Secondary Science and Mathematics Teachers' Environmental Issues Engagement through Socioscientific Reasoning. Eurasia Journal of Mathematics, Science and Technology Education, 15(6), em1693. https:/ / doi.org/10.29333/ ejmste/103561

*Smith, G. G., Besalti, M., Nation, M., Feldman, A., Laux, K. (2019). Teaching Climate Change Science to High School Students Using Computer Games in an Intermedia Narrative. Eurasia Journal of Mathematics, Science and Technology Education, 15(6), em1698. https:// doi.org/10.29333/ ejmste/103570

*Zhao, P., Anderson, C. W., Scott, E., Draney, K., Kim, J. (2019). How Chinese and American Students Construct Explanations of Carbon-Transforming Processes. Eurasia Journal of Mathematics, Science and Technology Education, 15(6), em1688. https:/ / doi.org/10.29333/ejmste/103067

\section{http://www.ejmste.com}

